\title{
Perbandingan Karakteristik Distribusi Butiran Hujan yang Berasal dari Awan Laut dan Awan Darat di Kototabang
}

\author{
Nur Faddillah ${ }^{1}$, Marzuki ${ }^{1, *}$, Wendi Harjupa ${ }^{2}$, Toyoshi Shimomai ${ }^{3}$, Hiroyuki \\ Hashiguchi $^{4}$ \\ ${ }^{1}$ Jurusan Fisika, Universitas Andalas, Padang, Indonesia \\ ${ }^{2}$ LAPAN, Bandung, Indonesia \\ ${ }^{3}$ Interdisciplinary Faculty of Science and Engineering, Shimane University, Japan \\ ${ }^{4}$ Research Institude for Sustainable Humanosphere, Kyoto University \\ *marzuki@fmipa.unand.ac.id
}

\begin{abstract}
ABSTRAK
Karakteristik distribusi ukuran butiran hujan atau raindrop size distribution (RDSD) dari hujan yang berasal dari awan laut dan awan darat di Kototabang, Sumatera Barat, telah dibandingkan. Asal hujan diamati menggunakan X-band Doppler radar (XDR) selama proyek Coupling Processes in the Equatorial Atmosphere (CPEA)-I (10 April 2004 - 9 Mei 2004). Data RDSD berasal dari pengamatan two-dimensional video disdrometer (2DVD). RDSD dimodelkan dengan distribusi gamma dan parameternya didapatkan menggunakan metode momen. Dari penelitian ini terlihat bahwa intensitas curah hujan yang tinggi lebih banyak pada hujan dari awan darat dibandingkan dengan yang dari awan laut. Selain itu, butiran hujan yang berukuran besar pada awan darat lebih banyak daripada awan laut. Banyaknya butiran hujan dengan ukuran yang besar ini berdampak kepada nilai radar reflectivity $(Z)$ pada awan darat yang lebih besar dibandingkan dengan awan laut untuk intensitas curah hujan yang sama. Hal ini mengakibatkan persamaan $Z-R$ antara awan darat dan awan laut berbeda dimana nilai koefisien $A$ dari persamaan $Z-R$ untuk awan darat lebih besar daripada awan laut. Dengan demikian, perbedaan karaktersitik RDSD antara awan darat dan laut sebaiknya dipertimbangkan dalam pengembangan radar meteorologi di kawasan tropis. Penggunaan $Z$ - $R$ tunggal $\left(Z=200 R^{1,6}\right)$ untuk mengkoversi data radar cuaca di Sumatera terutama Sumatera Barat tidak akan akurat terutama untuk hujan dari awan laut.

Kata kunci: distribusi butiran hujan (RDSD), awan darat, awan laut, Kototabang
\end{abstract}

\begin{abstract}
Characteristics of raindrop size distribution (RDSD) of precipitation from maritime and continental clouds at Kototabang during the first campaign of Coupling Processes in the Equatorial Atmosphere (10 April 2004 - 9 May 2004) had been investigated. The origin of precipitation was observed by using the $X$ band Doppler radar (XDR) observation and the RDSD of each precipitation type was collected by the two-dimensional video disdrometer (2DVD). The RDSD was parameterized by modified gamma distribution and its parameter was calculated by the moment method. It was found that the frequency of heavy rain from continental cloud was higher than maritime cloud. Moreover, the concentration of large sized drop in continental cloud was larger than maritime cloud. As consequence, the radar reflectivity factor (Z) for continental cloud was much larger than maritime cloud for the same rainfall rate so that Z$R$ equation $\left(Z=A R^{b}\right)$ between continental and maritime cloud is different in which the value of $A$ for continental cloud was larger than maritime cloud. Thus, the usage of single $Z-R\left(Z=200 R^{1,6}\right)$ equation to convert the radar meteorology data in West Sumatra may lead to the error of quantitative precipitation estimation from the radar.
\end{abstract}

Keywords: raindrop size distribution (RDSD), maritime cloud, continental cloud, Kototabang

\section{PENDAHULUAN}

Raindrop size distribution (RDSD) merupakan distribusi butiran hujan per ukuran dalam volume sampel pengamatan selama interval waktu tertentu (Jameson dan Kostinski, 2001). RDSD memiliki banyak kegunaan diantaranya dalam bidang remote sensing untuk pengembangan radar dan satelit meteorologi (Coppens dan Haddad, 2000), pemodelan atenuasi gelombang mikro (Owolawi, 2011), mengukur tingkat erosi tanah (Harikumar, 2009), konversi data radar cuaca (Kozu dkk., 2006) dan sebagainya.

Karakteristik RDSD dipengaruhi oleh berbagai faktor seperti monsun, lokasi, waktu dan tipe hujan, serta Madden Jullian Oscillation (MJO). Menurut Kozu dkk. (2006), karakteristik RDSD dipengaruhi oleh monsun. Misalnya, perbedaan RDSD antara periode-periode monsun teramati lebih kuat di India dibandingkan di Indonesia dan Singapura karena aktivitas monsun di India lebih kuat dibandingkan dengan di Indonesia dan Singapura. Selain faktor monsun, 
RDSD juga bervariasi terhadap lokasi, waktu, dan tipe hujan (Rosenfeld dan Ulbrich, 2003). Pada daerah di kawasan tropis terutama yang dekat dengan lautan, nilai RDSD antara pagi, siang dan malam hari memperlihatkan perbedaan yang signifikan. Jumlah butiran hujan berukuran kecil lebih banyak di pagi hari dibandingkan dengan siang dan malam hari (Marzuki dkk., 2009; 2013a; 2016 ). Faktor lain yang juga mempengarui RDSD di kawasan tropis adalah Madden Jullian Oscillation (MJO). Jumlah butiran hujan berukuran besar lebih banyak pada fase tidak aktif MJO dibandingkan fase aktif MJO (Kozu dkk., 2005; Marzuki dkk., 2010a; 2016).

Selain faktor yang disebutkan di atas, RDSD juga dipengaruhi oleh asal awan hujan. Berdasarkan asalnya, awan dapat dibagi menjadi dua yaitu awan laut dan awan darat. Awan darat (continental cloud) merupakan awan yang terbentuk di wilayah daratan, sedangkan awan laut (maritime cloud) merupakan awan yang terbentuk di lautan atau samudera. Ada beberapa perbedaan antara awan dari laut dan awan yang berasal dari daratan. Pertama, konsentrasi butiran awan yang berukuran besar pada awan laut lebih tinggi dibandingkan awan darat. Kedua, pada awan darat konsentrasi butiran awan yang berukuran kecil sangat tinggi (Rosenfeld dan Lensky, 1998). Perbedaan yang ketiga adalah awan laut menjadi hujan melalui proses hangat (warm process) dimana proses tumbukan adalah faktor yang dominan dalam hal ini. Di sisi lain, awan darat menjadi hujan melalui proses dingin (cold process) yang melibatkan fase es (Rosenfeld dan Ulbrich, 2003). Keempat, pergerakan udara ke atas (updraft) dan ke bawah (downdraft) pada awan laut lebih lemah dibandingkan dengan awan darat (Zipser dan Lutz, 1994).

Perbedaan karakteristik antara awan darat dan awan laut yang disebutkan di atas akan menimbulkan perbedaan RDSD. Tenorio dkk. (2012) menguji dugaan ini dengan meneliti karakteristik RDSD antara awan darat dan awan laut di Brazil. Mereka menemukan bahwa jumlah butiran hujan yang berasal dari awan laut lebih besar dari awan darat tetapi jumlah butiran hujan berukuran besar $(D>2 \mathrm{~mm})$ lebih banyak pada awan darat. Perbedaan RDSD ini mempengaruhi akurasi pengamatan intensitas curah hujan (sering disimbolkan dengan $R$ ) menggunakan data radar reflectivity $(Z)$. Mereka mendapatkan persamaan $Z=146 R^{1,27}$ untuk hujan dari awan laut dan $Z=256 R^{1,27}$ untuk hujan dari awan darat. Penelitian Tenorio dkk. (2012) dengan jelas membuktikan bahwa RDSD dari hujan yang ditimbulkan oleh awan darat dan laut adalah berbeda, tetapi penelitian lain yang mendukung temuan ini tidak ada. Oleh karena itu, tulisan ini akan meneliti tentang perbedaan antara RDSD dari hujan yang ditimbulkan oleh awan darat dan awan laut di Kototabang, Sumatera Barat.

RDSD yang diamati di dalam penelitian ini adalah selama proyek Coupling Processes in the Equatorial Atmosphere (CPEA)-I (9 April 2004 - 10 Mei 2004). CPEA-I merupakan proyek pengamatan secara internasional tentang karakteristik atmosfer di Indonesia (Fukao, 2006). Selama CPEA-I, dioperasikan berbagai instrumen termasuk radar cuaca seperti $X$-band Doppler radar (XDR) dan alat untuk mengukur butiran hujan (two-dimensional video disdrometer). Dengan adanya radar cuaca tersebut, pergerakan hujan dari Samudera Hindia ke daratan Sumatera dapat diamati, begitu pula sebaliknya. Oleh karena itu, data yang didapatkan bisa digunakan untuk mengamati karakteristik RDSD yang berasal awan laut dan awan darat. Penelitian mengenai RDSD di Kototabang telah banyak dilakukan (Kozu dkk., 2005; Marzuki dkk., 2009; 2010a; 2010b; 2012; 2013a; 2013b; 2016) tetapi belum ada yang meneliti tentang perbedaan RDSD yang berasal dari awan laut dan awan darat.

\section{METODE}

Data RDSD berasal dari pengamatan two-dimensional video disdrometer (2DVD). 2DVD merupakan alat berbasis sensor optik yang dapat mengukur distribusi, kecepatan jatuh butiran dan bentuk butiran hujan. Alat ini diproduksi oleh Joanneum Research, The Institute for Applied Systems Technology di Graz, Austria. 2DVD dipasang di Lembaga Penerbangan Antariksa Nasional (LAPAN) wilayah Kototabang, disekitar kompleks EAR (0,20 LS, 100,32 BT). Secara umum, 2DVD memiliki 3 komponen, yaitu SU (Sensor Unit), OEU (Outdoor Electronic Unit) dan IUT (Internal User Terminal). Resolusi data 2DVD yang digunakan adalah 
2 menit dengan ukuran bin 0,2 mm (Marzuki dkk., 2010b). Hanya RDSD dengan intensitas curah hujan $>0,1 \mathrm{~mm} / \mathrm{jam}$ yang digunakan.

Untuk menentukan arah pergerakan awan hujan, digunakan $X$-band Doppler radar (XDR). XDR ini berlokasi di Sungai Puar, sekitar $20 \mathrm{~km}$ arah selatan-tenggara dari lokasi 2DVD (Kawashima dkk., 2006). Data XDR ini berupa citra radar yang berupa constant altitude plan position indicator (CAPPI) yang dirata-ratakan setiap 30 menit. Dari citra radar ini dapat ditentukan hari atau waktu hujan yang berasal dari awan laut atau awan darat.

RDSD pertama kali dikelompokkan dan dirata-ratakan berdasarkan beberapa kelas intensitas curah hujan. RDSD dengan intensitas hujan yang sama dari awan laut dibandingkan dengan RDSD dari awan darat. Hal ini akan memberikan informasi awal dan umum tentang perbedaan RDSD antara awan darat dan awan laut. Untuk melihat karakteristik RDSD lebih detail, RDSD dimodelkan dengan distribusi gamma sebagai berikut:

$$
N(D)=\frac{N_{T} \Lambda^{\mu+1}}{\Gamma(\mu+1)} D^{\mu} \exp (-\Lambda D)
$$

dimana $N(D)$ adalah fungsi RDSD $\left(\mathrm{mm}^{-1} \mathrm{~m}^{-3}\right), N_{T}$ adalah parameter intercept dengan satuan $\mathrm{m}^{-3}$, $\mu$ adalah parameter bentuk (shape) dan $\Lambda$ merupakan parameter slope dari distribusi dalam satuan $\mathrm{mm}^{-1}$. Parameter gamma RDSD $\left(\mu, N_{T}\right.$, dan $\Lambda$ ) dihitung menggunakan metode momen. Metode momen dikembangkan berdasarkan prinsip bahwa semua parameter hujan merupakan fungsi RDSD yang secara umum dapat ditulis sebagai berikut:

$$
\begin{gathered}
M_{x}=\int_{0}^{\infty} N(D) D^{x} d D \\
M_{x}=N_{T} \frac{\Gamma(\mu+x+1)}{\Lambda^{x} \Gamma(\mu+1)}
\end{gathered}
$$

dimana $M$ adalah momen dan $x$ adalah pangkat diameter butiran. Dalam penelitian ini digunakan $x=3$, 4, dan 6 dan Persamaan (2) didapat:

$$
\begin{aligned}
& M_{3}=N_{T} \frac{\Gamma(\mu+4)}{\Lambda^{3} \Gamma(\mu+1)} \\
& M_{4}=N_{T} \frac{\Gamma(\mu+5)}{\Lambda^{4} \Gamma(\mu+1)} \\
& M_{6}=N_{T} \frac{\Gamma(\mu+7)}{\Lambda^{6} \Gamma(\mu+1)}
\end{aligned}
$$

$M_{3}$ menunjukkan liquid water content (LWC), $M_{4}$ menunjukkan intensitas curah hujan $(R), M_{6}$ menunjukkan radar reflectivity $(Z)$. Dengan mengkombinasikan Persamaan (4-5, parameter gamma RDSD dalam Persamaan (1) dapat dihitung sebagai berikut (Kozu dan Nakamura, 1991; Marzuki dkk., 2010b; 2012):

$$
\mu=\frac{11 G-8+[G(G+8))]^{0,5}}{2(1-G)}
$$

dengan

$$
\begin{gathered}
G=\frac{M_{4}^{3}}{M_{3}^{2} M_{6}} \\
N_{T}=\frac{\Lambda^{3} M_{3} \Gamma(\mu+1)}{\Gamma(\mu+4)} \\
\Lambda=\frac{(\mu+4) M_{3}}{M_{4}}
\end{gathered}
$$


dimana $D_{m}\left(=M_{4} / M_{3}\right)$ adalah massa-berat diameter rata-rata. Tahap terakhir yang dilakukan adalah menghitung persamaan $Z-R$. Persamaan $Z-R$ dihitung dengan menggunakan regresi linear dalam skala logaritmik.

\section{HASIL DAN DISKUSI}

\subsection{Citra Radar untuk Hujan dari Awan Darat dan Awan Laut}

Sebelum membahas karakteristik butiran hujan dari hujan darat dan laut, terlebih dahulu ditampilkan contoh citra awan untuk kedua tipe awan tersebut. Gambar 1 merupakan contoh citra radar untuk hujan yang berasal dari laut pada tanggal 19 April 2004. Pergerakan hujan dari daratan Sumatera menuju lautan (Samudera Hindia) terlihat dengan jelas pada bagian utara Kototabang. Hujan dengan arah pergerakan seperti ini (darat-laut) disebut dengan hujan yang berasal dari awan darat pada pembahasan berikutnya.

Tabel 1 memperlihatkan waktu pengamatan selama CPEA-I dimana awan darat teramati dengan jelas. Hujan dari awan darat secara umum berlangsung sekitar 40 - 66 menit. Hal ini memperlihatkan bahwa hujan dari awan darat berlangsung dengan durasi yang singkat dan intensitas yang tinggi.

Tabel 1 Hujan yang berasal dari awan darat selama CPEA-I

\begin{tabular}{ccccc}
\hline Tanggal & Jam $(\mathbf{W I B})$ & Durasi & $\boldsymbol{R m a x}$ & $\overline{\boldsymbol{R}}$ \\
\hline 11 April 2004 & $12.40-13.20$ & 40 menit & 35,00 & 14,2 \\
15 April 2004 & $18.08-18.54$ & 46 menit & 49,75 & 15,0 \\
19 April 2004 & $16.28-17.34$ & 66 menit & 36,30 & 4,5 \\
20 April 2004 & $12.38-13.20$ & 42 menit & 50,20 & 9,0 \\
\hline
\end{tabular}
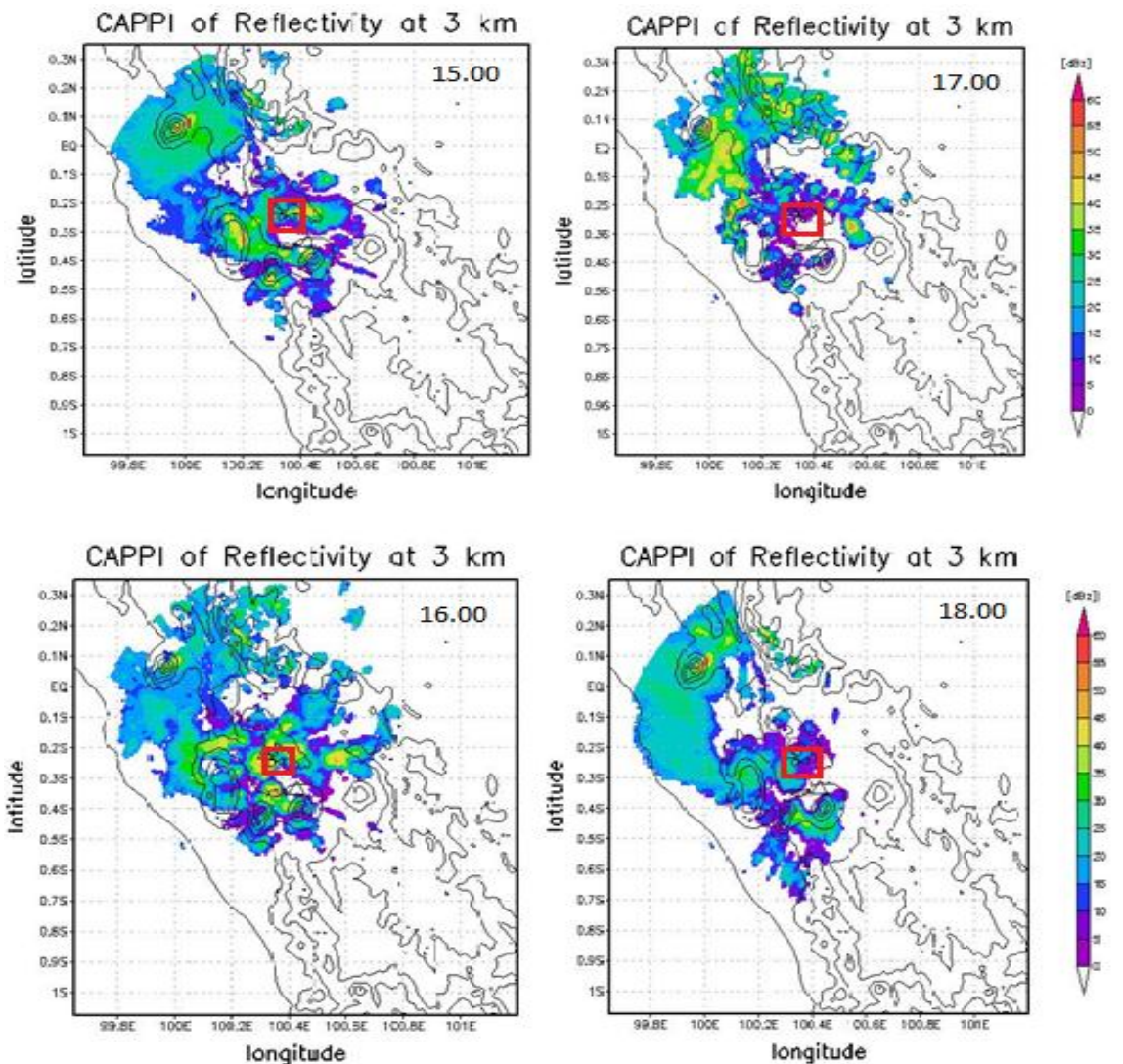

Gambar 1 Citra radar untuk hujan yang berasal dari awan darat tanggal 19 April 2004 pukul $15.00-18.00 \mathrm{WIB}$

Gambar 2 memperlihatkan pergerakan awan hujan yang berasal dari laut (Samudera Hindia) bergerak menuju daratan Sumatera pada tanggal 5 Mei 2004. Hujan dengan arah 
pergerakan seperti ini disebut dengan hujan dari awan laut pada pembahasan berikutnya. Tabel 2 memperlihatkan waktu pengamatan yang dikategorikan sebagai awan laut di dalam penelitian ini. Berbeda dengan hujan yang berasal dari awan darat, hujan yang dihasilkan oleh awan laut memiliki durasi yang lebih lama tetapi dengan intensitasnya lebih kecil.

Tabel 2 Hujan yang berasal dari awan laut selama CPEA-I

\begin{tabular}{ccccc}
\hline Tanggal & Jam (WIB) & Judul Kolom & $\boldsymbol{R m a x}$ & $\overline{\boldsymbol{R}}$ \\
\hline 24 April 2004 & $00.04-03.50$ & 226 menit & 9,72 & 1,24 \\
5 Mei 2004 & $12.56-20.24$ & 488 menit & 21,45 & 2,65 \\
6 Mei 2004 & $14.00-17.34$ & 214 menit & 20,5 & 2,03 \\
\hline
\end{tabular}
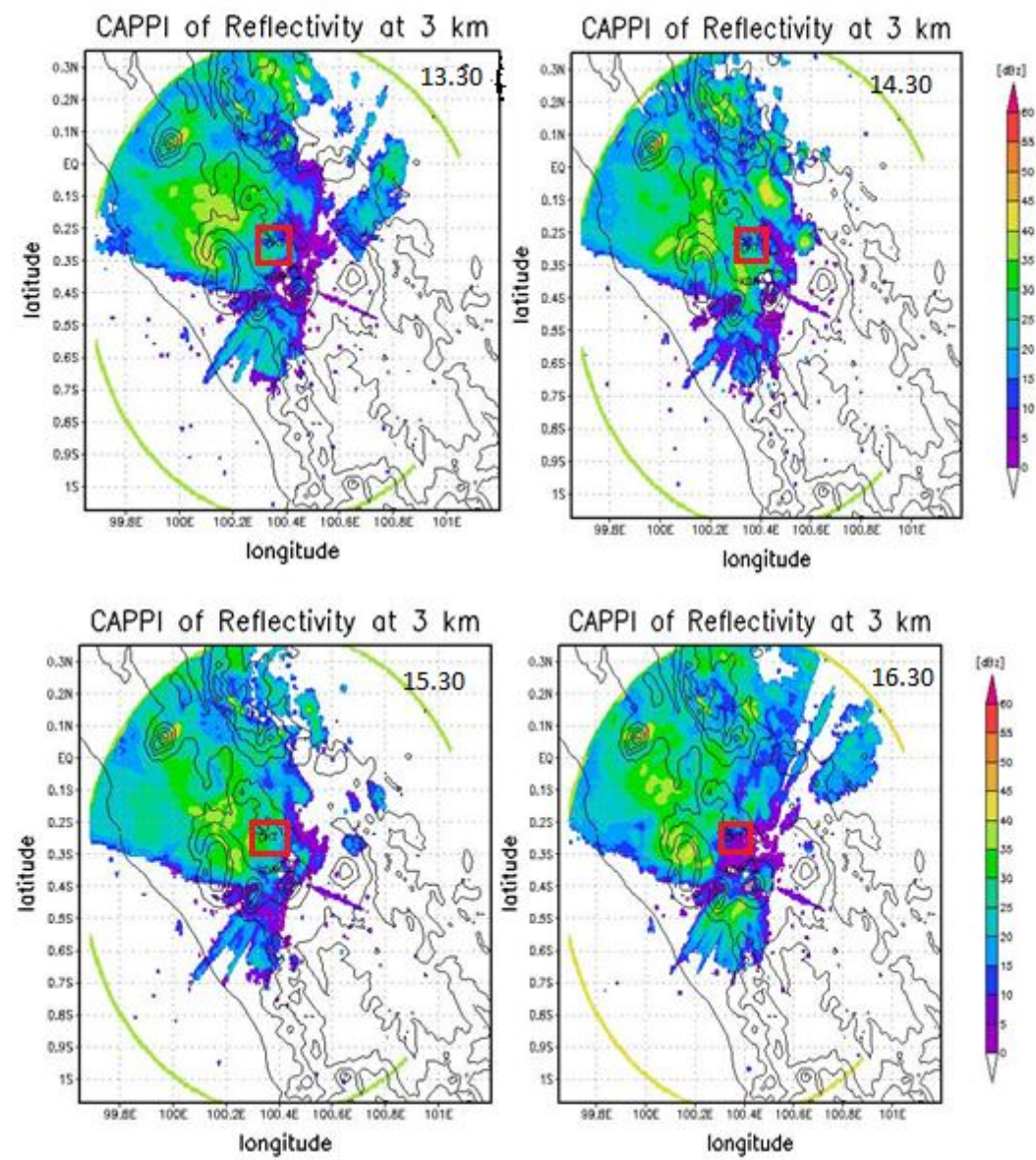

Gambar 2 Citra radar untuk hujan yang berasal dari awan laut tanggal 5 Mei 2004 pukul $13.03-16.30 \mathrm{WIB}$

\subsection{RDSD Rata-Rata}

Gambar 3 menunjukkan perbandingan rata-rata RDSD antara awan darat dan awan laut dari data yang terdapat pada Tabel 1 dan Tabel 2. Data dikelompokkan menjadi berbagai kategori hujan dengan mengacu pada penelitian Tokay dan Short (1996). Dapat dilihat bahwa konsentrasi butiran hujan berukuran kecil $(<1 \mathrm{~mm})$ untuk hujan yang berasal dari awan laut lebih tinggi dibandingkan dengan awan darat. Sebaliknya, konsentrasi butiran hujan berukuran besar ( $>2 \mathrm{~mm}$ ) untuk hujan yang berasal dari awan laut lebih rendah dibandingkan dengan awan darat. Hasil penelitian di Kototabang ini konsisten dengan hasil penelitian tentang RDSD dari awan darat dan laut di Brazil (Tenorio dkk., 2012).

Perbedaan konsentrasi butiran antara awan darat dan awan laut semakin jelas dengan peningkatan intensitas curah hujan. Hal ini seiring dengan semakin lebarnya RDSD dengan peningkatan intensitas curah hujan. Misalnya, pada hujan ekstrim (Gambar 3f), perbedaan konsentrasi antara butiran hujan darat dan laut pada diameter $3 \mathrm{~mm}$ sekitar $10^{2}$ jauh lebih besar dibandingkan dengan hujan ringan (Gambar 3b) yaitu sekitar 10. 
Untuk lebih jelasnya perbedaan antara RDSD hujan darat dan laut, dihitung parameter untuk RDSD rata-rata dari Gambar 3 menggunakan Persamaan 7-10. Tabel 3 memperlihatkan rekapitulasi data dan hasil fitting untuk gambar tersebut. Jumlah data bervariasi dalam setiap kategori hujan dimana hujan dengan kategori sangat ringan memiliki jumlah data paling banyak. Data dengan kategori sangat deras dan ekstrim untuk awan laut jumlahnya kurang dari 10 sehingga hal ini kemungkinan mempengaruhi RDSD rata-rata. Namun, perbedaan jumlah ini tidak akan mempengaruhi kesimpulan penelitian ini karena perbedaan RDSD antara awan darat dan laut teramati pada semua intensitas curah hujan, tidak hanya pada sangat deras dan ekstrim.
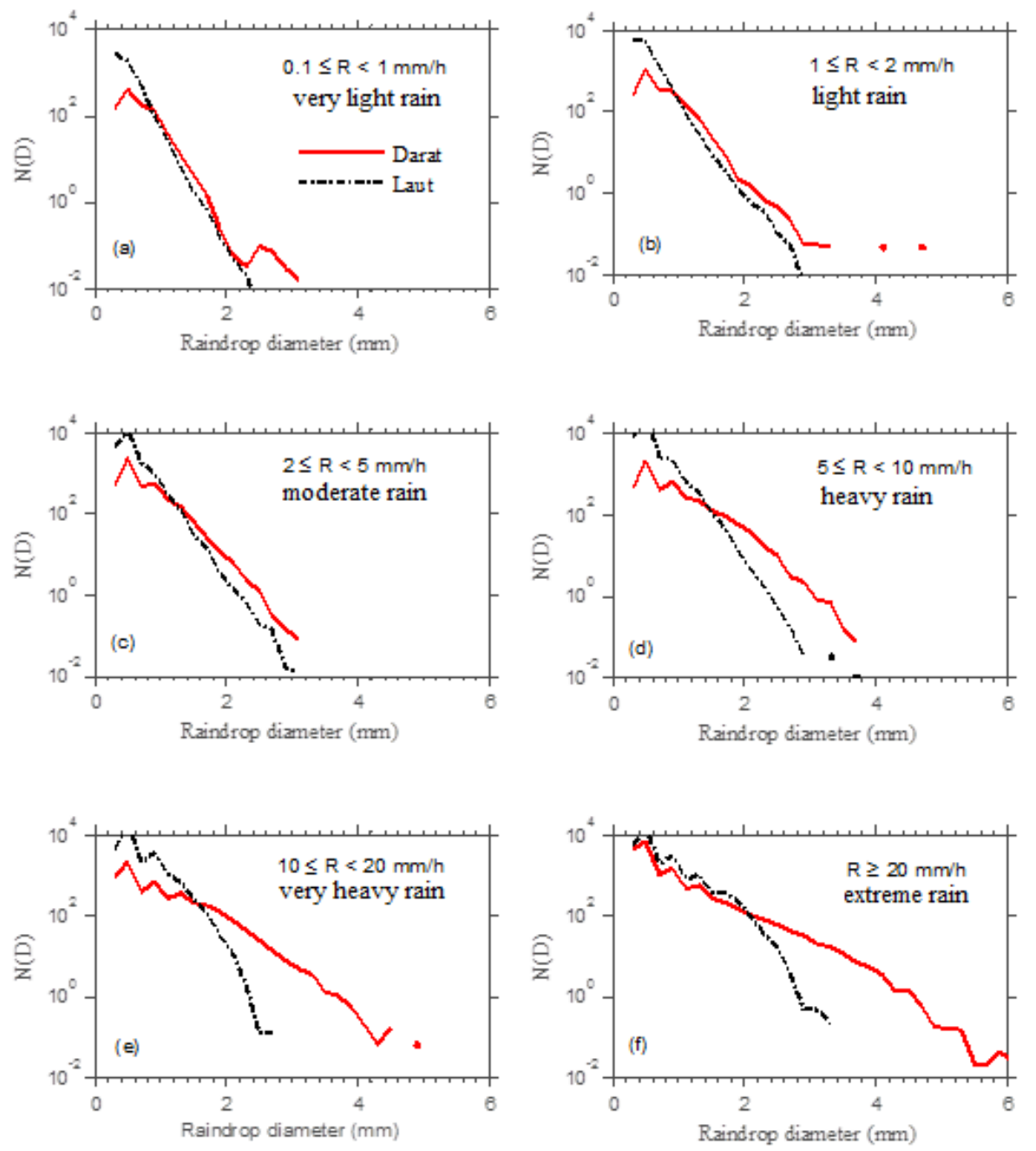

Gambar 3 Citra RDSD rata-rata pada berbagai kategori hujan. (a) Sangat ringan (very light) (b) Ringan (light) (c) Sedang (moderate) (d) Deras (heavy) (e) Sangat Deras (very heavy) (f) Ekstrim (extreme)

Parameter RDSD $\left(\Lambda, N_{T}\right.$, dan $\left.D_{m}\right)$ meningkat dengan meningkatnya intensitas curah hujan (Tabel 3). Hal ini menandakan bahwa semakin tinggi intensitas curah hujan semakin banyak jumlah butiran dan semakin banyak pula jumlah butiran yang berukuran besar. Seperti pada Gambar 3, Tabel 3 juga menunjukkan bahwa untuk semua intensitas curah hujan jumlah total butiran $\left(N_{T}\right)$ untuk awan laut lebih banyak daripada awan darat. Konsentrasi yang besar ini berasal dari butiran berukuran kecil. Karena butiran hujan yang berukuran kecil yang banyak, maka nilai $D_{m}$ dari awan laut jauh lebih kecil dibandingkan dengan awan darat.

Nilai $\mu$ dan $\Lambda$ untuk hujan yang berasal dari laut mempunyai nilai yang lebih kecil dibandingkan dengan hujan yang berasal dari darat, terutama untuk hujan sangat ringan hingga deras. Hal ini menandakan bahwa konsentrasi butiran berukuran kecil pada intensitas-intensitas hujan ini sangat tinggi sebagaimana yang terlihat pada Gambar 3. Nilai $\mu$ untuk hujan laut tersebut mendekati distribusi ekponensial $(\approx 0)$. 
Tabel 3 Parameter gamma RDSD untuk RDSD rata-rata

\begin{tabular}{ccccccccccc}
\hline \multirow{2}{*}{$\begin{array}{c}\text { Kategori } \\
\text { Hujan }\end{array}$} & \multicolumn{2}{c}{ Jumlah Data } & \multicolumn{2}{c}{$\boldsymbol{\mu}$} & \multicolumn{2}{c}{$\boldsymbol{\Lambda}\left(\mathbf{m m}^{-\mathbf{1}}\right)$} & \multicolumn{2}{c}{$\mathbf{N}_{\mathbf{T}}\left(\mathbf{m}^{-\mathbf{3}}\right)$} & \multicolumn{2}{c}{ Dm $(\mathbf{m m})$} \\
\cline { 2 - 10 } & Darat & Laut & Darat & Laut & Darat & Laut & Darat & Laut & Darat & Laut \\
\hline Sangat Ringan & 37 & 200 & 1,69 & 1,57 & 6,10 & 8,56 & 301 & 1794 & 0,93 & 0,65 \\
Ringan & 10 & 96 & 2,48 & 0,35 & 3,25 & 6,19 & 2992 & 8046 & 1,10 & 0,70 \\
Sedang & 12 & 100 & 1,79 & 0,86 & 5,07 & 6,12 & 1028 & 8453 & 1,14 & 0,79 \\
Deras & 7 & 45 & 2,51 & 0,56 & 4,24 & 5,37 & 657 & 16685 & 1,53 & 0,85 \\
Sangat Deras & 14 & 4 & 2,46 & 2,62 & 3,56 & 6,52 & 752 & 6100 & 1,82 & 1,02 \\
Ekstrim & 21 & 2 & 0,50 & 2,24 & 2,12 & 4,69 & 2110 & 4075 & 2,12 & 1,33 \\
\hline
\end{tabular}

\subsection{Parameter RDSD per menit}

Rata-rata RDSD telah memperlihatkan adanya perbedaan antara awan darat dan awan laut. Untuk lebih melihat karakteristik RDSD dari hujan yang berasal dari awan darat dan awan laut, maka dibahas parameter gamma dari data yang terekam setiap menit. Gambar 4 memperlihatkan histogram radar reflectivity (dBZ), intensitas curah hujan (dBR) dalam skala logaritmik dan parameter-parameter gamma. Frekuensi untuk setiap bin histogram dinormalisasi dengan jumlah total data. Dari gambar terlihat bahwa untuk $\mathrm{dBZ}>40$, frekuensi awan darat lebih tinggi dari pada awan laut. Ini menandakan bahwa proses konvektif kuat lebih banyak terjadi pada awan darat dibandingkan dengan awan laut yang juga terlihat dengan jelas dari intensitas curah hujan (Gambar 4b).
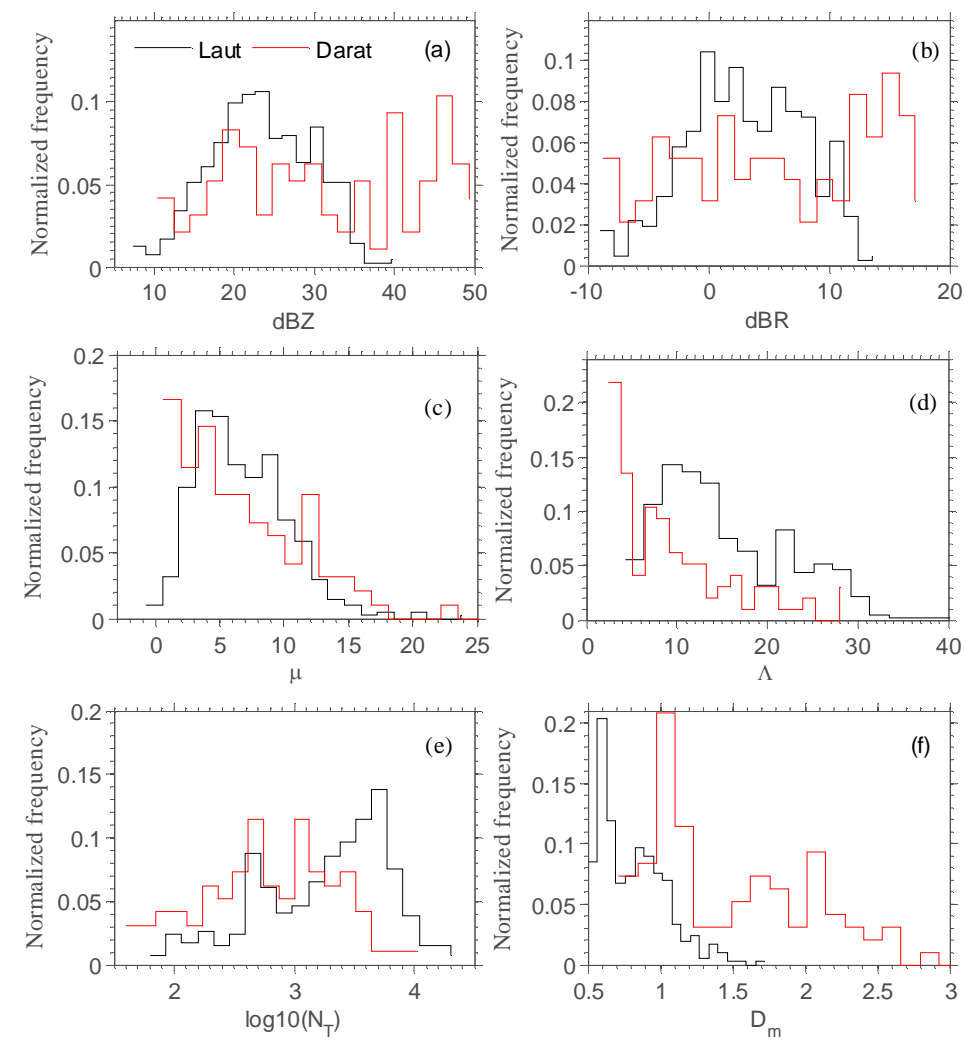

Gambar 4 Histogram antara frekuensi normalisasi untuk (a) dBZ (b) dBR (c) $\mu$ (d) $\Lambda$ (e) $\log _{10} N_{T}$ (f) $D_{m}$

Untuk $\mu$ dan $\Lambda$ (Gambar 4c,d), pada nilai-nilai yang besar frekuensi pada awan laut lebih tinggi dibandingkan dengan awan darat. Nilai $\mu$ dan $\Lambda$ yang besar biasanya dimiliki oleh RDSD dengan intensitas curah hujan yang kecil (Tabel 4). Oleh karena itu, karakteristik $\mu$ dan $\Lambda$ (Gambar 4c,d) konsisten dengan karakteristik distribusi intensitas curah hujan (Gambar 4b) dimana frekuensi hujan berintensitas rendah pada awan laut lebih tinggi dibandingkan dengan 
awan darat. Perbedaan yang paling signifikan teramati untuk nilai $D_{m}$ dimana hampir semua RDSD dari awan laut mempunyai nilai $D_{\mathrm{m}}<2 \mathrm{~mm}$. Hal ini menandakan bahwa butiran hujan berukuran besar lebih sedikit pada awan laut.

\subsection{Persamaan Z-R}

Salah satu aplikasi terpenting dari data RDSD adalah untuk membentuk persamaan $Z-R$ $\left(Z=A R^{b}\right)$ yang dipakai untuk mengkonversi nilai $Z$ dari radar meteorologi menjadi intensitas curah hujan $(R)$. Dalam penelitian ini persamaan $Z-R$ dihitung melalui tiga cara dan semuanya melalui regresi linear dalam skala logaritma. Yang pertama adalah sumbu $-y$ digunakan untuk $R$ dan sumbu $-x$ digunakan untuk $Z$. Hal ini digunakan karena parameter yang diketahui oleh radar adalah $Z$ dan yang ingin didapatkan adalah $R$. Cara kedua yaitu persamaan $Z-R$ seperti biasa, dengan sumbu $-y$ adalah $Z$ dan sumbu $-x$ adalah $R$. Cara ini adalah yang paling banyak digunakan. Ketiga, persamaan $Z-R$ dihitung dengan menetapkan nilai $b=1,4$. Penetapan nilai $\mathrm{b}$ $=1,4$ digunakan pada beberapa radar meteorologi (Marzuki dkk., 2016).

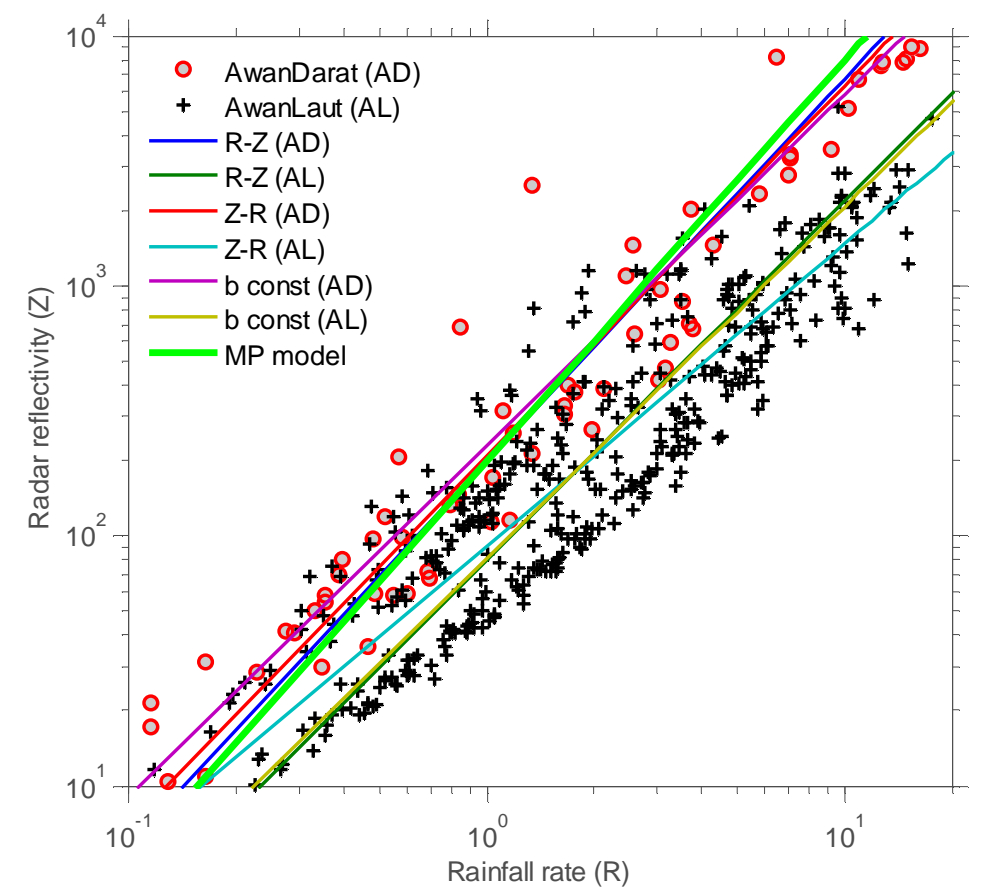

Gambar 5 Plot Z terhadap R bersama dengan hasil regresi persaamaan Z- $R$ menggunakan tiga metode untuk awan laut dan awan darat.

Gambar 5 memperlihatkan plot $Z$ terhadap $R$ dengan hasil regresi menggunakan tiga metode yang telah dijelaskan. Persamaan $Z-R$ dari hasil regresi dapat dilihat pada Tabel 4. Radar reflectivity $(\mathrm{Z})$ dari awan darat lebih tinggi dari awan laut untuk semua intensitas curah hujan. Hal ini juga terlihat dari lebih tingginya koefisien nilai $A$ untuk awan darat dibandingkan awan laut. Karakteristik $Z$ dan persamaan $Z-R$ ini konsisten dengan Sub-bab 3.2 dan 3.3 dimana pada semua intensitas curah hujan konsentrasi butiran yang besar lebih banyak pada awan darat dibandingkan dengan awan laut. Hal inilah yang menyebabkan $Z$ awan darat lebih tinggi dibandingkan dengan awan laut untuk intensitas hujan yang sama karena $Z$ itu sangat dipengaruhi oleh butiran hujan yang berukuran besar $\left(Z \cong D^{6}\right)$.

Hasil regresi untuk semua metode persamaan $Z-R$ sedikit berbeda dengan nilai persamaan $Z-R$ yang umum digunakan pada radar meteorologi yaitu Persamaan MarshallPalmer (MP) dengan $Z=200 R^{1,6}$ (Marshall dan Palmer 1948). Hal ini terjadi karena persamaan MP diturunkan dari RDSD di Hawai sedangkan data dalam penelitian ini berasal dari kawasan tropis. Walaupun persamaan MP didapatkan dari Hawai, persamaan ini telah digunakan oleh sebagian besar radar meteorologi di dunia, termasuk Indonesia. 
Hasil yang didapatkan untuk awan darat di Kototabang di dalam penelitian ini mendekati persamaan yang didapatkan oleh Marzuki dkk. (2013a) yaitu $Z=210 R^{1,39}$. Tenorio dkk. (2012) mendapatkan persamaan $Z-R$ untuk hujan dari awan laut adalah $Z=146 R^{1,27}$ dan untuk awan darat adalah $Z=256 R^{1,27}$. Dengan demikian, nilai koefisien $A$ dari awan darat juga lebih tinggi dibandingkan dengan awan laut, konsisten dengan yang ditemukan di dalam penelitian ini. Perbedaan nilai koefisien $A$ dan $b$ dalam penelitian ini dengan yang didapatkan oleh Tenorio dkk. (2012) kemungkinan disebabkan oleh perbedaan instrumen dan jumlah data yang digunakan.

Tabel 4 Persamaan $Z-R$ dari RDSD untuk awan darat dan awan laut

\begin{tabular}{ccc}
\hline Metode & Darat & Laut \\
\hline$R-Z$ & $Z=199 R^{1,52}$ & $\mathrm{Z}=80 R^{1,43}$ \\
$Z-R$ & $Z=211 R^{1,50}$ & $\mathrm{Z}=91 R^{1,20}$ \\
$b$ konstan & $Z=230 R^{1,40}$ & $\mathrm{Z}=82 R^{1,40}$ \\
\hline
\end{tabular}

\section{KESIMPULAN}

Hasil penelitian ini memperlihatkan bahwa adanya perbedaan intensitas curah hujan dan RDSD antara hujan yang dihasilkan dari awan laut dan awan darat. Intensitas curah hujan dari awan darat lebih tinggi dibandingkan dengan awan laut. Butiran hujan yang berukuran besar lebih banyak ditemukan pada hujan dari awan darat daripada awan laut. Banyaknya ukuran butiran hujan yang berukuran besar ini berdampak kepada nilai radar reflectivity $(\mathrm{Z})$ pada awan darat yang lebih besar daripada awan laut untuk intensitas curah hujan yang sama. Hal ini mengakibatkan persamaan $Z-R$ antara awan darat dan awan laut berbeda dimana nilai koefisien $A$ yang ada dalam persamaan $Z-R$ untuk awan darat lebih besar daripada awan laut. Dengan demikian, penggunaan $Z-R$ tunggal $\left(Z=200 R^{1,6}\right)$ untuk mengkoversi data radar cuaca di Sumatera terutama Sumatera Barat tidak akurat terutama untuk hujan dari awan laut.

\section{UCAPAN TERIMA KASIH}

Terima kasih kepada Dr. Masayuki Kawashima dan tim Institute of Low Temperature Science, Hokkaido University, Japan yang telah mengoperasikan X-band Doppler radar (XDR) selama proyek CPEA-I.

\section{DAFTAR PUSTAKA}

Coppens, D. dan Haddad, Z. S., 2000, Effect of Raindrop Size Distribution Variations on Microwave Brightness Temperature Calculation, Journal of Geophysical Research, Vol. 105, No. 19, hal. $483-489$.

Fukao, S., 2006, Coupling Processes in the Equatorial Atmosphere (CPEA): A Project Overview, Journal of the Meteorological Society of Japan, Vol. 84A, hal. 1 - 18.

Harikumar, R., 2009, Study on Tropical Rain With Special Reference to Rain Drop Size Distribution and Integral Rain Parameters Using Ground-Based and Satellite Measurements, Thesis, Cochin University of Science and Technology, India.

Jameson, A. R. dan Kostinski, A. B., 2001, What is a Raindrop Size Distribution, Bulletin of American Meteorological Society, Vol. 82, No. 6, hal. 1169-1177.

Kawashima, M., Y. Fujiyoshi, M. Ohi, T. Honda, T. Kozu, T.Shimomai, and H. Hashiguchi, "Overview of Doppler radar observations of precipitating cloud systems in Sumatera island during the first CPEA campaign," J. Meteor. Soc. Japan, 84A,pp. 33-56, 2006.

Kozu, T., Reddy, K. K., Mori, S., Thurai, M., Ong, J. T., Rao, D. N., dan Shimomai, T., 2006, Seasonal and Diurnal Variations of Raindrop Size Distribution in Asian Monsoon Region, Journal of the Meteorology Society of Japan, Vol. 84A, hal. 195 - 209.

Kozu, T., Shimomai, T., Akramin, Z., Marzuki, Shibagaki, Y., dan Hashiguchi H., 2005, Intraseasonal Variation of Raindrop Size Distribution at Koto Tabang, West Sumatra, Indonesia, Geophysical Research Letters, Vol. 32, Hal. 1 - 4.

Marshall, J.S. and Palmer, W.M., 1948. The distribution of raindrops with size. J. Meteorol., 5, 165-166. 
Marzuki, Kozu, T., Shimomai, T., Hashiguchi, H., Randeu, W. L., dan Shibagaki, Y., 2009, Diurnal variation of rain attenuation obtained from measurement of raindrop size distribution in equatorial Indonesia, IEEE Trans. Ant. Propag., Vol. 57, Hal. 11911196.

Marzuki, Kozu, T., Shimomai, T., Randeu, W. L., Hashiguchi, H., and Vonnisa, M.: Raindrop size distributions of convective rain over equatorial Indonesia during the first CPEA campaign, Atmos. Res., 96, 645-655, 2010a.

Marzuki, M., Randeu, W. L., Schoenhuber, M., Bringin, V. N., Kozu, T. and Shimomai, T.: Raindrop size distribution parameters of distrometer data with different bin sizes, IEEE Trans. Geosci. Remote Sens. 48, 3075-3080, 2010 b.

Marzuki, Randeu, W. L., Kozu, T., Shimomai, T., Schoenhuber, M. and Hashiguchi, H.: Estimation of raindrop size distribution parameters by maximum likelihood and Lmoment methods: Effect of discretization, Atmos. Res., 112, 1-11, 2012.

Marzuki, Randeu, W. L., Kozu, T., Shimomai, T., Hashiguchi, H., dan Schoenhuber, M., 2013a, Raindrop Axis Ratios, Fall Velocities and Size Distribution Over Sumatra From 2D Video Disdrometer Measurement, Atmospheric Research, Vol. 119, Hal. 23-37.

Marzuki, M., Hashiguchi, H., Yamamoto, M. K., Mori, S., and Yamanaka, M. D.: Regional variability of raindrop size distribution over Indonesia, Ann. Geophys., 31, 1941-1948, doi:10.5194/angeo-31-1941-2013, 2013b.

Marzuki, Hashiguchi, H., Kozu, T., Shimomai, T., Shibagaki, Y., Takahashi, Y., 2016, Precipitation Microstructure in Different Madden-Julian Oscillation Phases over Sumatra, Atmospheric Research, Vol. 168, pp. 121-138.

Owolawi, P., 2011, Raindrop Size Distribution Model for the Prediction of Rain Attenuation in Durban, PIERS Online, Vol. 7, No. 6, hal. 516-523.

Rosenfeld, D. dan Lensky, I.M., 1998, Satellite-Based Insights into Precipitation Formation Processes in Continental and Maritime Convective Clouds, Bulletin of American Meteorological Society, Vol. 9, No. 11, hal. 2457-2466.

Rosenfeld, D. dan Ulbrich, C.W., 2003, Cloud Microphysical Properties, Processes, and Rainfall Estimation Opportunities, Meteorological Monographs, Vol. 52, hal. 237 258.

Tenorio, R.S., Moraes, M.C.D.S., dan Sauvageot, H., 2012, Raindrop Size Distribution and Radar Parameters in Coastal Tropical Rain Systems of Northeastern Brazil, Journal of Applied Meteorological and Climatology, Vol. 51, hal. 1960-1970.

Tokay, A. dan Short, D. A., 1996, Evidence from Tropical Raindrop Spectra of the Origin of Rain from Statiform Versus Convective Clouds, Journal Applied Meteorology, Vol. 35 , hal $355-371$.

Zipser, E.J. dan LeMone M.A., 1980: Cumulonimbus Vertical Velocity Events in GATE. Part II: Synthesis and Model Core Structure, Journal Atmosphere Science, Vol. 37, Hal. 2458- 2469. 